\title{
Impact of Human Capital on Aggregate Organization Performance in Malaysia
}

\author{
Clara Schneider \\ (Humboldt University of Berlin) \\ Cahya Budhi Irawan \\ (STIE Jaya Negara Tamansiswa Malang)
}

\begin{abstract}
This study examines the impact of human capital on the aggregate performance of companies in Malaysia using the OECD's Human Capital Acquisition Index (OECD) using the Ordinary Least Squares (OLS) qualitative method. Based on the estimation results we find that human capital acquisition has a positive relationship with company performance in Malaysia.
\end{abstract}

Keywords: Human Capital Acquisition, Human Capital, Southeast Asia

\section{Background}

Human capital is a very important capital in today's modern era. Human capital determines the competitiveness of companies. Increasing human capital becomes important by training and educating employees. Education and training are ways to increase human capital (Widarni \& Bawono, 2020). Payroll and education taxes can influence investment in human capital in the workplace. Payroll taxes are negatively related to human capital investment. Taxes increase the cost of investing in human capital because of reduced income. An increase in the payroll tax imposed on employee salaries will suppress human capital investment due to reduced income for workers (Ratten, 2021). On-the-job training in the workplace by working while practising can also be used in improving human resources. This can be done where junior employees learn from their senior employees. This kind of training can increase the company's performance in the aggregate. Human capital is a very important factor in determining the productivity of an economy. The different qualities of human capital are believed to be able to cause two economies that have identical amounts of labour, physical capital, natural resources and technology to produce different outputs.

Humans are a form of capital, like physical capital and technology. Human capital is a qualitative dimension of human resources. The qualitative dimension of human resources, such as expertise and skills, possessed by a person will affect that person's productive ability. Skills, skills and knowledge can be improved through a good educational process and maintained health conditions. Expenditures for education and health are investments because, like investing in buildings or land, they will generate returns in the future. Expenditures on education, training and health will improve one's health and knowledge so that the productivity and income of that person will increase in the future. The skills that exist in humans will increase productivity directly and increase the ability of an economy to develop and adopt new technology. From the results of this explanation, it can be concluded that the initial hypothesis or conclusion is as follows: 
Human capital accumulation has an impact and is positively related to Aggregate performance.

\section{Literature Review}

Work experience reflects on-the-job training and on-the-job learning or learning. Training and knowledge in the workplace can improve employee performance so that work experience is positively related to performance (Birkhead, 2020). Work experience has an impact on performance. The more experiences a person has the better or better the performer.

Formal education and taxes have an impact on productivity. Formal education is a description of the human capital investment made by employees (Alemán, 2020). Formal education develops a mindset and critical thinking power so that formal education can have an impact on increasing learning which in turn has an impact on increasing the absorption of learning so that the development of human capital is faster and better. Employee education is an important consideration in employee recruitment. Formal education is one of the mechanisms for increasing human capital (MacKay et al, 2020). Apart from formal education, work experience is also an important factor in determining employee recruitment. Work experience is a reflection of on-the-job training. Formal education needs to be accompanied by job training or work experience. So that human capital can be formed from education, training, and experience at work (Parker \& Crabtree, 2020).

Highly skilled employees, of course, can perform better than unskilled employees. Training for less experienced employees is needed to improve performance and ensure that these employees perform well. Expertise can be formed from experience, education, and training (Preber, 2014). Worker tax or income tax is a tax levied by the government on employee income or employee salary. Of course, this tax will reduce employee income so that taxes are negatively related to human capital investment. So that taxes can be said to have an effect on increasing human capital, but are negative. The higher the tax, the more hindered the increase in employee human capital will be (Booth et al, 2016).

Human capital is a collection of human expertise and abilities in completing work obtained through the process of education, training and experience so as to form certain skills that can be used to complete work to earn income. Human capital investment certainly requires financing that can be obtained from previously earned income so that it is hoped that an increase in income through increased performance is expected (Widarni, 2020).

\section{Research methods}

This study examines the acquisition of human resources based on an index from the OECD, which includes income tax or worker tax, formal education, work experience, and job training. We investigate the relationship between income tax, formal education, work experience, and job training on aggregate firm performance in Malaysia using Ordinary Least Squares (OLS) with the following equation:

$Y_{t}=C_{t}+\beta_{1} T_{t 1}+\beta_{2} E_{t 2}+\beta_{3} E_{t 3}+\beta_{4} \mathrm{Jt}_{t 4}+e_{t}$

Where, 
$\mathrm{Y}=$ Performance

$\mathrm{T}=\mathrm{Tax}$

$\mathrm{Ed}=$ Education

$\mathrm{Er}=$ Experience

$\mathrm{M}=$ Job Training

$\mathrm{e}=$ error term

\section{Results and Discussion}

The estimation results are as follows:

$\mathrm{Y}=0.431617-0.421242 * \mathrm{~T}+0.701224 * \mathrm{Ed}+1.223724 * \mathrm{Er}+0.961361 * \mathrm{Jt}$

From the OLS estimation results, tax affects the aggregate performance of -0.421242 counting scale. If the tax increases by $1 \%$, the performance will decrease by 0.421242 . Education has a positive effect along with other variables. Table 1 describes the estimation results as follows:

Table 1. Estimation Results

\begin{tabular}{|c|c|c|c|}
\hline \multicolumn{4}{|c|}{ Dependent variable Y } \\
\hline Variable & Coefficient & t-Statistic & Prob. \\
\hline $\mathrm{C}$ & 0.431617 & 1.121623 & 0.0008 \\
\hline $\mathrm{T}$ & -0.421242 & -0.124107 & 0.0039 \\
\hline Ed & 0.701224 & 0.613127 & 0.0072 \\
\hline $\mathrm{Er}$ & 1.415131 & 1.314521 & 0.0041 \\
\hline $\mathrm{Jt}$ & 0.961361 & 1.412621 & 0.0017 \\
\hline R-squared & 0.811412 & Mean dependent var & 4.31416 \\
\hline Adjusted R-squared & 0.806181 & S.D. dependent var & 6.17255 \\
\hline S.E. of regression & 12.2131 & Sum squared resid & 8.23195 \\
\hline F-statistic & 52.1211 & Durbin-Watson stat & 0.94391 \\
\hline Prob(F-statistic) & 0 & & \\
\hline
\end{tabular}

Based on the estimation results described in table 1. It shows that the acquisition of human capital has a positive impact on performance. Taxes are a factor that must be determined wisely in fiscal policy because they have a huge impact on the real sector. Improving the quality of education and employment opportunities are the main keys in improving performance which in aggregate drive economic growth.

\section{Conclusion}

Human capital is an important factor in improving performance. Human capital can be developed and shaped through education and training mechanisms as well as work experience. The acquisition of human capital has an impact on the performance of companies on an aggregate basis in Malaysia.

\section{Reference :}

Alemán,E.(2020).Latin American Politics.London : Sage Publishing 
Birkhead,G.S., Morrow,C.B. ,Pirani,S.(2020).Essentials of Public Health.Burlington : Jones \& Bartlett Learning

Booth,P., Bourne,R., Meakin,R.(2016).Taxation, Government Spending and Economic Growth. London: The Institute of Economic Affairs

MacKay,B., Arevuo,M. ,Meadows,M.(2020).Strategy: Theory, Practice, Implementation. Oxford : Oxford University Press

Parker,J., Crabtree,S.A.(2020).Human Growth and Development in Adults: Theoretical and Practice Perspectives. Bristol: The Policy Press

Preber,B.J.(2014).Financial Expert Witness Communication: A Practical Guide to Reporting and Testimony. Hoboken : John Wiley and Sons

Ratten,V.(2021).Innovation and Entrepreneurship in Sport Management.Cheltenham :Edward Elgar

Widarni,E.L., Bawono,S.(2020).Human Capital Investment For Better Business Performance. Singapore: Triplenine Communication

Widarni,E.L.(2020).Human Capital Frameworks: How to Build a Strong Organization.New York : Lulu Press 